\title{
The Length and Flexibility of the 2-Substituent of 9-Ethyladenine Derivatives Modulate Affinity and Selectivity for the Human $A_{2 A}$ Adenosine Receptor
}

\author{
Ajiroghene Thomas, ${ }^{[a]}$ Michela Buccioni, ${ }^{[a]}$ Diego Dal Ben, ${ }^{[a]}$ Catia Lambertucci, ${ }^{[a]}$ \\ Gabriella Marucci, ${ }^{[\mathrm{a}]}$ Claudia Santinelli, $^{[\mathrm{a}]}$ Andrea Spinaci, ${ }^{[\mathrm{a}]}$ Sonja Kachler, ${ }^{[\mathrm{b}]}$ \\ Karl-Norbert Klotz, ${ }^{[\mathrm{b}]}$ and Rosaria Volpini ${ }^{[\mathrm{a}]}$
}

The $A_{2 A}$ adenosine receptor $\left(A_{2 A} A R\right)$ is a key target for the de-
velopment of pharmacological tools for the treatment of cen-
tral nervous system disorders. Previous works have demon-
strated that the insertion of substituents at various positions
on adenine leads to $A_{2 A} A R$ antagonists with affinity in the mi-
cromolar to nanomolar range. In this work, a series of 9-ethyla-
denine derivatives bearing phenylalkylamino, phenylakyloxy or
phenylakylthio groups of different lengths at the 2-position
were synthesised and tested against the human adenosine re-
ceptors. The derivatives showed sub-micromolar affinity for these membrane proteins. The further introduction of a bromine atom at the 8-position has the effect of improving the affinity and selectivity for all ARs and led to compounds that are able bind to the $A_{2 A}$ AR subtype at low nanomolar levels. Functional studies confirmed that the new adenine derivatives behave as $A_{2 A} A R$ antagonists with half-maximal inhibitory concentration values in the nanomolar range. Molecular modelling studies provide a description of the possible binding mode of these compounds at the $A_{2 A} A R$ and an interpretation of the affinity data at this AR subtype.

\section{Introduction}

Extracellular adenosine (Ado) is the endogenous ligand of membrane receptors belonging to the $\mathrm{P} 1$ purinergic receptor family and classified as $A_{1}, A_{2 A}, A_{2 B}$ and $A_{3}$ subtypes $\left(A_{1} / A_{3}\right.$ and $A_{2 A} / A_{2 B}$ are coupled to $G_{i}$ and $G_{s}$ protein signalling, respectively). ${ }^{[1]}$ These proteins, named adenosine receptors (ARs), regulate many physiological and pathological functions in the central nervous system (CNS) and the periphery and are potential drug targets for diseases such as cardiovascular and immune disorders, renal failure, inflammatory conditions, and neurological, psychiatric and neurodegenerative disorders. ${ }^{[2]}$ As a consequence, a number of medicinal chemistry and pharmacology studies on AR ligands have been reported by industry or academic research groups, which have led to the discovery and development of compounds with potential applications as drugs. The $A_{2 A} A R$ is the target subtype for which the first $A R$ ligand has been approved for market (the selective agonist Regadenoson, commercialised as Lexiscan by the Astellas Pharma Company, for myocardial perfusion imaging). ${ }^{[3]}$ This protein is of particular interest for its roles in the CNS and in neurodege-

[a] Dr. A. Thomas, Dr. M. Buccioni, Prof. D. Dal Ben, Prof. C. Lambertucci, Prof. G. Marucci, C. Santinelli, A. Spinaci, Prof. R. Volpini

School of Pharmacy, Medicinal Chemistry Unit, University of Camerino, via S. Agostino 1, 62032 Camerino, Macerata (Italy)

E-mail: rosaria.volpini@unicam.it

[b] Dr. S. Kachler, Prof. K.-N. Klotz

Institut für Pharmakologie und Toxikologie, Universität Würzburg, Versbacher Str. 9, 97078 Würzburg (Germany)

(iD The ORCID identification number(s) for the author(s) of this article can be found under http://dx.doi.org/10.1002/cmdc.201500595. nerative disorders, that is, Parkinson's disease, and selective antagonists of the $A_{2 A} A R$ are currently being developed for therapeutic applications. The recent approval for manufacturing and marketing of the $A_{2 A} A R$ selective antagonist Istradefylline by Nouriast, Kyowa Hakko Kirin Co., Ltd., in Japan represents the first authorisation to the market of an AR antagonist as an anti-parkinsonian agent. ${ }^{[4]}$

In many papers, we have described the effect of the introduction of substituents at the 2-, 8- and 9-position on the adenine scaffold for the affinity and selectivity of the four AR subtypes. ${ }^{[5]}$ In particular, the substitution of the ribose moiety of the natural agonist Ado with an ethyl group leads to the compound 9-ethyladenine, which behaves as an AR antagonist endowed with micromolar affinity for the human $A_{1}$ and $A_{2 A} A R$ subtypes (inhibition constants $K_{\mathrm{i}} \mathrm{A}_{1}=7440 \mathrm{nM}, K_{\mathrm{i}} \mathrm{A}_{2 \mathrm{~A}}=$ $2200 \mathrm{nM}$ ). However, this molecule is not able to bind the $A_{2 B}$ and $A_{3}$ ARs at concentrations up to $100 \mu \mathrm{M}$. Further modification by introduction of a bromine atom in the 8-position of this molecule led to 8-bromo-9-ethyladenine, a compound that shows enhanced affinity at all receptor subtypes. This compound behaves as an $A_{2 A} A R$ receptor antagonist and is endowed with moderate selectivity, especially against the $A_{1} A R$ subtype. ${ }^{[5 a]}$ Similarly, the introduction of an 8-bromo substituent led to a general improvement in the $A_{2 A} A R$ affinity for a series of adenine derivatives substituted in the 9-position with different alkyl groups. ${ }^{[5 g]}$ From investigation of the other positions of the purine core, it was found that the presence of a hindered phenethylamino or a phenylethyloxy group in the 2-position of 9-ethyladenine favours the interaction of the re- 
sultant compound with all ARs. ${ }^{[5 d]}$ Even in this case, the additional introduction of an 8-bromo substituent enhances the affinity for all ARs with an increased $A_{2 A}$ AR selectivity. ${ }^{[\mathrm{d}]}$ Furthermore, a study on AR agonists showed that the introduction of arylalkylthio groups in the 2-position of Ado leads to compounds presenting nanomolar affinity for the ARs with a fair selectivity for the $A_{2 A} A R^{[6]}$ We also recently reported a series of 2-alkylamino-substituted 9-propyladenine derivatives that showed that the different length of the alkyl spacer (methyl to propyl) within the substituent at the 2-position has the effect to modulate the affinity for the different AR subtypes. ${ }^{[7]}$ On this basis, in the search for novel $A_{2 A} A R$ antagonists, we designed and synthesised compounds 4-9 and 11-20, which consist of 9-ethyladenine and 8-bromo-9-ethyladenine analogues bearing, in the 2-position, phenylalkylamino, phenylakyloxy or phenylakylthio groups of various lengths and flexibilities (Schemes 1-4, Table 1 below). The new compounds were tested in binding assays with human recombinant $A_{1}, A_{2 A}$ and $A_{3} A R s$ and in a functional cyclic adenosine monophosphate ( $C A M P$ ) assay with the human recombinant $A_{2 B}$ AR. Functional studies with the GloSensor ${ }^{\mathrm{TM}}$ CAMP assay were performed to assess the antagonist profile of selected synthesised derivatives. Furthermore, molecular modelling studies were performed to interpret and explain the affinity of the newly synthesised adenine derivatives at the $A_{2 A} A R$.

\section{Results and Discussion}

\section{Chemistry}

The new 2-substituted 9-ethyladenine derivatives $(\mathbf{4}, \mathbf{6}, \mathbf{7}, \mathbf{9}$, 11-20) were synthesised from commercially available 2,6-dichloropurine (1), which was initially treated with iodoethane in the presence of potassium carbonate as a catalyst and $\mathrm{N}, \mathrm{N}$-dimethylformamide (DMF) as a solvent (Scheme 1) ${ }^{[8]}$ Compounds $\mathbf{5}$ and $\mathbf{8}$ were previously reported and were synthesised from 9-ethyl-2-iodoadenine (10). ${ }^{[\mathrm{aa}]}$

The reaction of $\mathbf{2}$ with liquid ammonia at room temperature led to 2-chloro-9-ethyladenine (3) in $93 \%$ yield. 2-Chloro-9-ethyladenine (3) was used for the preparation of the 2-phenylalkylamino- and 2-phenylalkyloxy-9-ethyladenines (Scheme 2). For the synthesis of the 2-thio derivatives, 9-ethyl-2-iodoadenine $(10)^{[5 a]}$ was used as the starting material (Scheme 3).

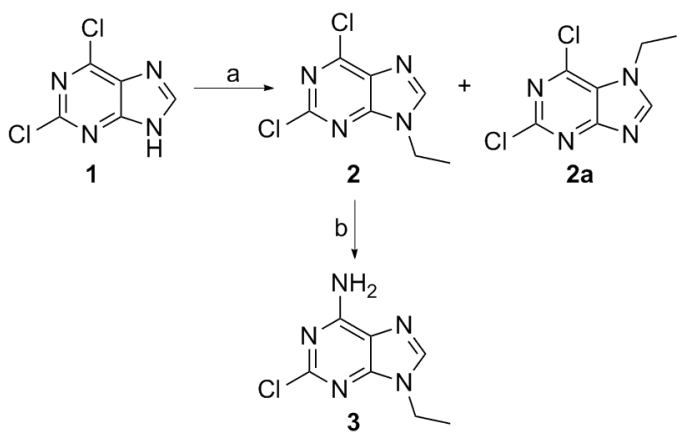

Scheme 1. Preparation of 2-chloro-9-ethyladenine (3). Reagents and conditions: a) $\mathrm{K}_{2} \mathrm{CO}_{3}, \mathrm{CH}_{3} \mathrm{CH}_{2} \mathrm{l}, \mathrm{DMF}, \mathrm{RT}, 6 \mathrm{~h}$; b) $\mathrm{NH}_{3}, \mathrm{RT}, 20 \mathrm{~h}$.

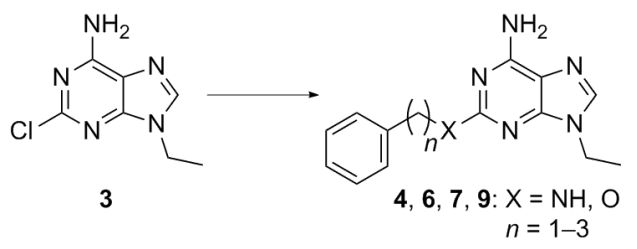

Scheme 2. Preparation of 2-phenylalkylamino- and 2-phenylalkyloxy-9-ethyladenines. Reagents and conditions: $\mathrm{RNH}_{2}, 130^{\circ} \mathrm{C}, 24-28 \mathrm{~h}$ or $\mathrm{ROH}, \mathrm{NaOH}, 85-$ $105^{\circ} \mathrm{C}, 3-4 \mathrm{~h}$.

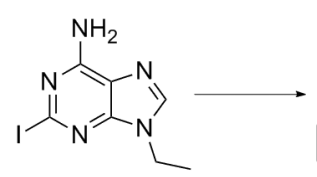

10

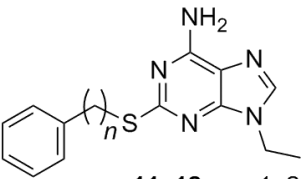

11, 12: $n=1,2$
Scheme 3. Preparation of 2-phenylalkylthio-9-ethyladenines. Reagents and conditions: $\mathrm{RSH}, \mathrm{NaOH}, 100^{\circ} \mathrm{C}, 24 \mathrm{~h}$.

The synthesis of 2-aminoadenine derivatives 4 and 6 was performed through the reaction of $\mathbf{3}$ with the suitable amine used as a solvent and with heating of the reaction mixture at high temperature $\left(T=130^{\circ} \mathrm{C}\right)$ for about $24 \mathrm{~h}$. The 2-alkoxyadenine derivatives 7 and 9 and the 2-thioadenine analogues 11 and 12 were obtained by using the suitable alcohol or thiol as a solvent in alkaline catalytic conditions, by addition of $\mathrm{NaOH}$, at high temperature $\left(T=85-105^{\circ} \mathrm{C}\right)$ for $3-4 \mathrm{~h}$ reaction time.

The 2-substituted adenine derivatives 4-9, 11 and 12 were, in turn, treated with $\mathrm{N}$-bromosuccinimide (NBS) in DMF at room temperature to introduce a bromine atom at the 8-position of the purine ring, which led to the corresponding 8bromo derivatives 13-20 (Scheme 4). The reactions were complete within 20-50 min, depending on the substituent present in the 2-position; the 2-thio derivatives $\mathbf{1 1}$ and $\mathbf{1 2}$ were the least reactive in the series. With respect to the synthesis of the 2-unsubstituted adenines reported previously, the reaction takes a relatively shorter time, which demonstrates the higher reactivity as a result of the presence of the substituent at the 2-position. ${ }^{[5 \mathrm{~g}]}$

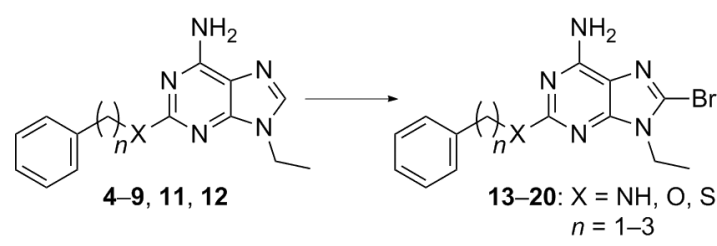

Scheme 4. Preparation of 8-bromo-substituted adenines. Reagents and conditions: NBS, DMF, RT, 20-50 min.

\section{Biological evaluation}

The synthesised compounds were tested in a radioligand binding assay with human recombinant ARs, expressed in Chinese hamster ovary $(\mathrm{CHO})$ cells, to evaluate their affinity for the $A_{1}$, 
$\mathrm{A}_{2 \mathrm{~A}}$ and $\mathrm{A}_{3}$ AR subtypes. $\left[{ }^{3} \mathrm{H}\right]$-2-chloro- $N^{6}$-cyclopentyladenosine (CCPA), $\left[{ }^{3} \mathrm{H}\right]-5^{\prime}-\mathrm{N}$-ethylcarboxamidoadenosine (NECA) and $\left[{ }^{3} \mathrm{H}\right]-$ 2-hexyn-2-yl- $N^{6}$-methyladenosine (HEMADO) were used as the respective radioligands. ${ }^{[9]}$ The results are reported as $K_{\mathrm{i}}$ values in nanomolar, with $95 \%$ confidence intervals in parentheses (Table 1). The $K_{i}$ values at the $A_{2 B} A R$ were calculated from the half-maximal inhibitory concentration $\left(\mathrm{IC}_{50}\right)$ values determined from analysis of the inhibition of NECA-stimulated adenylyl cyclase activity (Table 1). ${ }^{[9]}$ The derivatives 9-ethyladenine and 8bromo-9-ethyladenine are reported in Table 1 as reference compounds, together with the already reported compounds $\mathbf{5}$, 8, 14 and 17. As mentioned above, 9-ethyladenine shows micromolar affinity for the $A_{1}$ and $A_{2 A}$ ARs but is not able to bind the $A_{2 B}$ and $A_{3} A R s$, even at high concentrations (9-ethyladenine: $K_{\mathrm{i}} \mathrm{A}_{1}=7440 \mathrm{nM} ; K_{\mathrm{i}} \mathrm{A}_{2 \mathrm{~A}}=2200 \mathrm{nM} ; K_{\mathrm{i}} \mathrm{A}_{2 B}>30000 \mathrm{~nm}$; $\left.K_{\mathrm{i}} \mathrm{A}_{3}>100000 \mathrm{~nm}\right)$.

The introduction of a bromine atom in the 8-position or a phenylethylamino or phenylethyloxy group in the 2-position of 9-ethyladenine leads to compounds with improved affinity at all ARs with some selectivity for the $A_{2 A}$ AR subtype (8bromo-9-ethyladenine: $K_{\mathrm{i}} \mathrm{A}_{2 \mathrm{~A}}=52 \mathrm{nM} ; \mathrm{A}_{1} / \mathrm{A}_{2 \mathrm{~A}}=5 ; 5: K_{\mathrm{i}} \mathrm{A}_{2 \mathrm{~A}}=$ $\left.150 \mathrm{~nm} ; \mathrm{A}_{1} / \mathrm{A}_{2 \mathrm{~A}}=2 ; 8: K_{i} \mathrm{~A}_{2 \mathrm{~A}}=120 \mathrm{nM} ; \mathrm{A}_{1} / \mathrm{A}_{2 \mathrm{~A}}=1\right)$. Notably, the combination of these substitutions in the 8- and 2-positions gives further improvement of affinity (14: $K_{\mathrm{i}} \mathrm{A}_{1}=150 \mathrm{nM}$; $K_{\mathrm{i}} \mathrm{A}_{2 \mathrm{~A}}=19 \mathrm{nM} ; K_{\mathrm{i}} \mathrm{A}_{2 B}=690 \mathrm{nM} ; K_{\mathrm{i}} \mathrm{A}_{3}=3100 \mathrm{~nm} ; 17: K_{\mathrm{i}} \mathrm{A}_{1}=23 \mathrm{~nm}$; $K_{\mathrm{i}} \mathrm{A}_{2 \mathrm{~A}}=1.7 \mathrm{nM} ; K_{\mathrm{i}} \mathrm{A}_{2 \mathrm{~B}}=569 \mathrm{~nm} ; K_{\mathrm{i}} \mathrm{A}_{3}=1090 \mathrm{nM}$ ), with compound

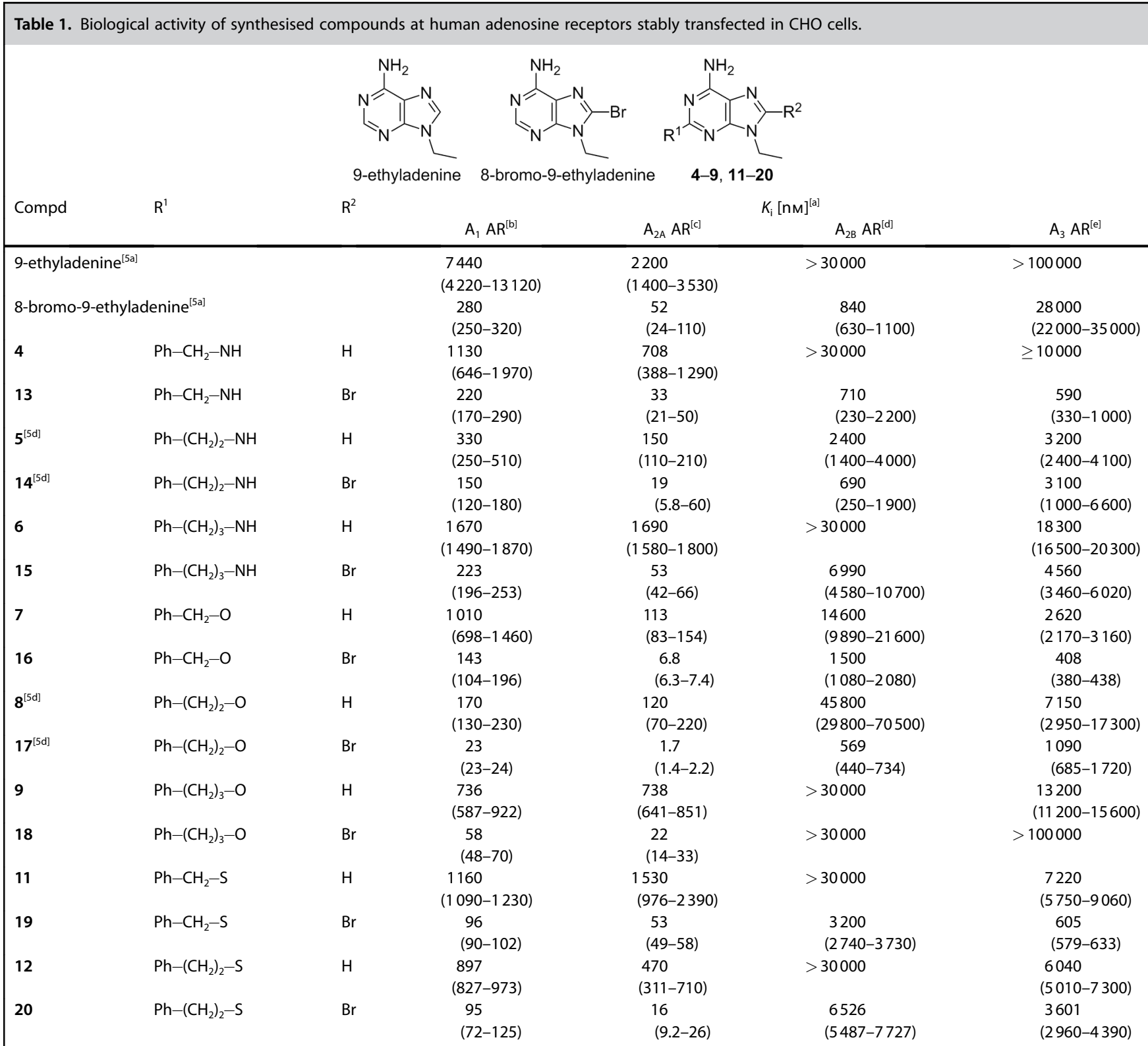

[a] $95 \%$ confidence intervals are given in parentheses. [b] Displacement of specific $\left[{ }^{3} \mathrm{H}\right] \mathrm{CCPA}$ binding in $\mathrm{CHO}$ cells stably transfected with human recombinant $A_{1} A R$. [c] Displacement of specific $\left[{ }^{3} \mathrm{H}\right] \mathrm{NECA}$ binding in $\mathrm{CHO}$ cells stably transfected with human recombinant $\mathrm{A}_{2 A} A R$. [d] $K_{i}$ values at the $\mathrm{A}_{2 B} A R$ were calculated from $\mathrm{IC}_{50}$ values determined by inhibition of NECA-stimulated adenylyl cyclase activity. [e] Displacement of specific [ $\left.{ }^{3} \mathrm{H}\right] \mathrm{HEMADO}$ binding in $\mathrm{CHO}$ cells stably transfected with human recombinant $A_{3} A R$. 
17 presenting the highest $A_{2 A} A R$ affinity and selectivity $\left(A_{1} /\right.$ $\left.A_{2 A}=14\right){ }^{[5 d]}$ We tested the effect of the introduction of a phenylalkylthio group of the same length in the 2-position of 9ethyladenine and the further modification by introduction of a bromine atom in the 8-position (12 and 20, respectively). Even these modifications on 9-ethyladenine give an improvement in AR affinity, with a slight selectivity for the $A_{2 A}$ AR maintained (12: $K_{\mathrm{i}} \mathrm{A}_{2 \mathrm{~A}}=470 \mathrm{nM} ; 20: K_{\mathrm{i}} \mathrm{A}_{2 \mathrm{~A}}=16 \mathrm{~nm}$ ), with the exception of compound 12 at the $A_{2 B} A R$. Compound 20 is even more active at the $A_{2 A} A R$ than the corresponding 2-phenylethylamino analogue 14 . The next step was to evaluate the effect of the variation of the length of the alkyl spacer within the 2-substituent. With consideration of the 2-arylalkylamino series, the modification of the ethyl spacer of the 2-substituent of $\mathbf{5}$ with a shorter methyl group leads to a decrease in AR affinity and $A_{2 A} A R$ selectivity. The substitution of the ethyl spacer with a propyl chain leads to an almost identical affinity at the $A_{2 A}$ and $A_{1}$ ARs $\left(6: K_{i} A_{1}=1670 n M ; K_{i} A_{2 A}=1690 \mathrm{~nm}\right)$. With regard to the 2-arylalkyloxy series, the modification of the ethyl spacer of the 2-substituent of $\mathbf{8}$ with a shorter methyl group has the effect of improving the affinity for almost all ARs and particularly the selectivity for the $A_{2 A}$ AR relative to the $A_{1} A R\left(7: K_{i} A_{2 A}=113 n M ; A_{1} / A_{2 A}=9\right)$. The substitution of the same ethyl spacer with a propyl chain decreases the affinity for all $A R s$ and leads to an almost identical affinity for the $\mathrm{A}_{2 \mathrm{~A}}$ and $\mathrm{A}_{1}$ ARs $\left(9: K_{\mathrm{i}} \mathrm{A}_{1}=736 \mathrm{nM} ; K_{\mathrm{i}} \mathrm{A}_{2 \mathrm{~A}}=738 \mathrm{~nm}\right)$. Finally, the affinity for the ARs shown by the 2-phenylalkylthio-substituted derivative $\mathbf{1 2}$ is decreased if its ethyl spacer is substituted by a shorter methyl group (11). The latter compound is also not selective for the $A_{2 A} A R$.

As expected, further modification of these compounds with the introduction of a bromine atom in the 8-position leads to molecules that present generally improved affinity at all of the ARs with respect to the corresponding 8-unsubstituted analogues. With consideration of the 2-arylalkylamino series, compounds 13 and 15 present a 20-30-fold increase of affinity at the $A_{2 A} A R$ with respect to the corresponding 8-unsubstituted analogues (4 and 6, respectively) and also show a fair selectivity versus the $\mathrm{A}_{1} A R\left(13: K_{\mathrm{i}} \mathrm{A}_{2 \mathrm{~A}}=33 \mathrm{nM} ; \mathrm{A}_{1} / \mathrm{A}_{2 \mathrm{~A}}=6.7 ; 15: K_{\mathrm{i}} \mathrm{A}_{2 \mathrm{~A}}=\right.$ $\left.53 \mathrm{~nm} ; A_{1} / A_{2 A}=4.2\right)$. It must also be noted that compound 13 presents an interesting affinity at the $A_{2 B}$ and $A_{3}$ ARs (13: $K_{\mathrm{i}} \mathrm{A}_{2 \mathrm{~B}}=710 \mathrm{nM} ; K_{\mathrm{i}} \mathrm{A}_{3}=590 \mathrm{nM}$ ). In any case, we do not observe an improvement of affinity and selectivity in this series with respect to those already reported for compound 14 . With regard to the 2-arylalkyloxy set of compounds, the introduction of a bromine atom in the 8-position of 7 and 9 (16 and 18, respectively) again improves the affinity for the $A_{2 A} A R$. Compound 16 is endowed with low nanomolar affinity at the $A_{2 A}$ AR (16: $K_{\mathrm{i}} \mathrm{A}_{1}=143 \mathrm{nM} ; K_{\mathrm{i}} \mathrm{A}_{2 \mathrm{~A}}=6.8 \mathrm{nM} ; K_{\mathrm{i}} \mathrm{A}_{2 B}=1500 \mathrm{nM} ; K_{\mathrm{i}} \mathrm{A}_{3}=$ $408 \mathrm{nM}$ ) and the best selectivity profile against the $A_{1} A R$ (about 21-fold), with a significant improvement relative to the already reported compound $\mathbf{1 7}$ that is its superior homologue. Interestingly, in the case of the 8-bromo-2-phenylpropyloxysubstituted derivative $\mathbf{1 8}$, we observe a complete loss of affinity for the $A_{3} A R$ and the affinity for the $A_{2 B} A R$ is not improved relative to the 8-unsubstituted analogue 9 . Finally, in consideration of the 2-arylalkylthio series, the introduction of a bromine atom in the 8-position of 11 leads to compound 19, which presents an improved affinity for all ARs and an interesting $K_{\mathrm{i}}$ value for the $A_{3} A R$. The selectivity for the $A_{2 A} A R$ is very low, particularly relative to the $A_{1} A R$ subtype.

If the results are taken together, the new 2-substituted compounds display, in general, $K_{\mathrm{i}}$ values ranging from micromolar to high nanomolar concentrations for all ARs, with more pronounced affinity for the $A_{2 A}$ and $A_{1} A R$ subtypes, whereas (as observed in previous reports) the corresponding 8-bromo-substituted derivatives show generally increased affinity at all ARs relative to the corresponding 8 -unsubstituted derivatives. The 2-arylalkyloxy substituents appear, in general, to provide higher affinity with respect to the corresponding 2-alkylamino or 2-alkylthio groups. The optimal alkyl spacer of the 2-substituent is the methylene or ethyl group beside the heteroatom, whereas the affinity significantly decreases with a propyl linker. The already reported compound 14 and the new compound 16 present the highest $A_{2 A} A R$ affinity and selectivity (versus the $A_{1} A R$ ), respectively, among all of the presented compounds.

To evaluate the functional activity of the new derivatives, representative compounds 14, 16, 17 and 20, which showed high $A_{2 A} A R$ affinity, were evaluated with the GloSensor ${ }^{T M}$ CAMP assay. ${ }^{[10]}$ The full AR agonist NECA and the $A_{2 A}$ AR antagonist 8-bromo-9-ethyladenine were tested as reference compounds. The results of this analysis are reported in Table 2. As expected, the reference compound NECA behaved as a full agonist with potency comparable to that reported in literature. ${ }^{[1]}$

\begin{tabular}{|c|c|c|c|}
\hline Compd & $\mathrm{EC}_{50}[\mathrm{~nm}]^{[\mathrm{a}]}$ & $\mathrm{IC}_{50}[\mathrm{nM}]^{[\mathrm{b}]}$ & $K_{\mathrm{i}}[\mathrm{nm}]$ \\
\hline NECA & $125 \pm 40$ & - & - \\
\hline 8-bromo-9-ethyladenine & - & $83 \pm 28$ & 52 \\
\hline 14 & - & $37 \pm 7$ & 19 \\
\hline 17 & - & $5.6 \pm 1$ & 1.7 \\
\hline 20 & - & $48 \pm 12$ & 16 \\
\hline 16 & - & $12 \pm 3$ & 6.8 \\
\hline
\end{tabular}

[a] Concentration of agonist required to produce $50 \%$ of the maximum effect. [b] Concentration of antagonists that produces $50 \%$ inhibition of the agonist effect. Each concentration was tested five times in triplicate, and values are given as the mean \pm standard error.

By contrast, 8-bromo-9-ethyladenine, the antagonistic behaviour of which has been demonstrated in different in vivo models of Parkinson's disease, ${ }^{[12]}$ behaved as an antagonist. The new compounds 14, 16, 17 and 20 were unable to activate the $A_{2 A} A R$ when tested alone (data not shown), whereas they counteracted, to different extents, the effect of the full agonist NECA and behaved as $A_{2 A} A R$ antagonists. Furthermore, they showed a very similar trend of activity to the binding data, with 8-bromo-9-ethyl-2-phenylethyloxyadenine (17; $\left.I C_{50}=5.6 \mathrm{nM}\right)$ presenting the highest potency at the human $A_{2 A} A R$. 


\section{Molecular modelling}

A molecular modelling study was performed to simulate and analyse the interaction of the synthesised molecules with the binding site of the human $A_{2 A} A R$. For this analysis, two crystal structures of the same protein solved in complex with ZM241385 antagonist (Protein Data Bank (PDB) ID: 3EML for $2.6 \AA$ resolution and PDB ID: 4EIY for $1.8 \AA$ resolution ${ }^{[13]}$ ) were employed. The $3 E M L$ crystal structure was re-modelled by removing the external $\mathrm{T} 4 \mathrm{~L}$ segment and by performing a building of missing receptor regions (the missing section of the extracellular 2 (EL2) or intracellular 3 (IL3) domains). The quality of the obtained $A_{2 A} A R$ model was checked within the Molecular Operating Environment (MOE, version 2010.10) suite. ${ }^{[14]}$ The two $A_{2 A} A R$ structures were then employed as molecular targets for docking analysis of developed compounds. All ligand structures were geometrically optimised with RHF/AM1 semiempirical calculations (by using the MOPAC ${ }^{[15]}$ software implemented in the MOE suite) and then subjected to docking analysis into the binding site of the human $A_{2 A} A R$ model by using AutoDock 4.2.6 software and the PyRx interface. ${ }^{[16]}$ Docking results were then imported into the MOE suite for post-docking analysis. The 2- and 2,8-substituted 9-ethyladenine derivatives present structural similarities with the co-crystallised ZM241385 compound and, as observed in previous docking studies of adenine derivatives at the $A_{2 A} A R^{[5 e, 7,17]}$ the docking results for these new molecules show a general binding mode that is comparable to that of the $A_{2 A} A R$ reference ligand (observed in the $3 E M L$ and $4 E I Y$ crystal structures). In detail (Figure 1, docking at the 3EML structure), the adenine scaffold of the compound is vertically orientated and positioned between residues of the EL2 and transmembrane (TM) 6 domains (Phe168 and Leu249 ${ }^{6.51},{ }^{[18]}$ respectively), which is similar to the position and orientation of the triazolotriazine scaffold of ZM241385 and of the same purine observed from the binding mode of the nucleoside Ado within another $A_{2 A} A R$ crystal structure (PDB ID: $2 \mathrm{YDO}^{[19]}$ ). The 6-amino group and the N7 nitrogen atom of adenine give a double hydrogen bond interaction with the Asn $253^{6.55}$ residue, whereas the 9-ethyl group is located between residues of the TM3, TM5 and TM6 domains (Leu85 $5^{3.33}$, Met177 $5.38, \operatorname{Trp} 246^{6.48}$ ).

With consideration of the substituent at the 2-position, as recently observed for a series of 2-substituted 9-propyladenines, ${ }^{[7]}$ an alkyl spacer of one or two carbon atoms within this group leads to high affinity, whereas a longer chain seems generally detrimental for the binding activity. The binding mode suggested by the docking results presents the 2-substituent pointing toward the extracellular space, with the phenyl ring located between EL2 and EL3 residues (Figure $1 \mathrm{~A}$ ). In the case of a propyl linker, the phenyl ring is externally located and, hence, is exposed to the solvent. Figure $1 \mathrm{~B}$ shows the binding cavity and compound 7 represented as molecular surfaces. This representation highlights the partial exposure to the extracellular environment of the phenyl ring within the 2substituent. Some docking conformations also present the 2substituent orientated towards residues belonging to the TM1, TM2 and TM3 domains but only for the derivatives containing

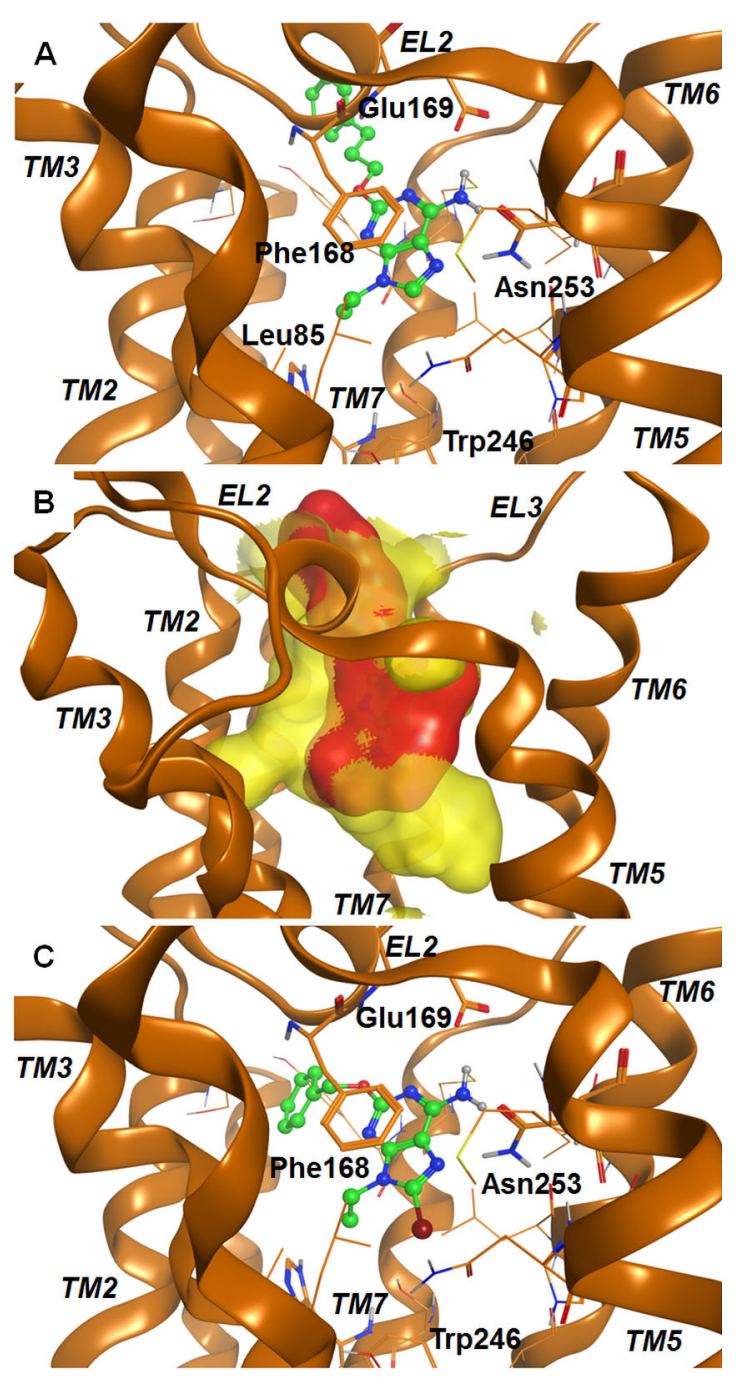

Figure 1. Docking conformations of analysed compounds at the $A_{2 A} A R$. A) Binding mode of compound 9, with an indication of the key ligand-receptor interaction residues. B) Representation of the same binding mode as a molecular surface; the cavity and ligand surfaces are represented as yellow and red, respectively. C) Binding mode of compound 16.

a methyl or ethyl spacer within this group (Figure 1C). This could be a factor explaining the generally lower affinity of compounds bearing a propyl spacer within the 2-substituent. In consideration of the effect of the heteroatom within the same group, the binding data highlight the generally higher affinity of the 2-alkoxy-substituted derivatives relative to the corresponding 2-alkylamino- and 2-alkylthio-substituted analogues. The 2-amino group of the 2-alkylamino series is conjugated to the aromatic purine scaffold and makes part of the 2substituent co-planar to the scaffold itself, which provides significantly higher rigidity to these derivatives than to the 2alkoxy analogues. In this sense, the higher flexibility of the latter derivatives could make these molecules more able to be accommodated within the binding cavity. This is particularly evident for the compounds bearing a methyl spacer within the 2-substituent (see the binding data of 7 and 16 for the 2alkoxy series and $\mathbf{4}$ and $\mathbf{1 3}$ as the corresponding 2-alkylamino analogues; Table 1). In the case of derivatives containing an 
ethyl spacer in the 2-position, the difference in flexibility between the two series would be less evident.

The presence of an 8-bromo substituent significantly improves the affinity for the $A_{2 A} A R$ relative to the corresponding 8 -unsubstituted derivatives. The docking results show the bromine atom as orientated towards the receptor core and located between residues of the TM3, TM5 and TM6 segments (Leu85 $5^{3.33}$, Thr88 3.36 , Met177 $7^{5.38}$, Trp246 6.48 Leu249 $9^{6.51}$ and His $250^{6.52}$ ). We hence performed a further analysis of the interactions between the compounds and the receptor binding site by using the IF-E 6.0 ${ }^{[20]}$ tool that is available from the SVL exchange service (Chemical Computing Group, Inc.) and that we previously employed for other analyses with ARs. ${ }^{[21]}$ The script calculates and displays atomic and residue interaction forces as $3 D$ vectors. It also calculates the per-residue interaction energies (values in $\mathrm{kcal} \mathrm{mol}^{-1}$ ), for which negative and positive energy values are associated to favourable and unfavourable interactions, respectively. Our analysis was focused on the interaction between the compounds and the residues located in the proximity of the 8-position. For this task, we employed the three 8-unsubstituted derivatives 5, 8 and 12 and the corresponding 8-bromo-substituted analogues 14, 17 and 20, respectively.

The results of this analysis are in good agreement for the two employed receptor structures and are reported in Tables 3 and 4 (for the docking results at the $3 E M L$ and $4 E I Y A_{2 A} A R$ structures, respectively). The data indicate that, in general, the 8-bromo-substituted compounds present a more favourable interaction with the binding site residues (located in the proximity of the 8-position) than the 8-unsubstituted derivatives, even if the difference between the respective estimated energy values is not large. These data could suggest that the role of the 8-bromo substituent might not be exclusively related to its interaction with the receptor. An additional role of this substituent could be possibly related to its ability to fill the TM3-TM5-TM6 hydrophobic sub-cavity and, hence, to provide the compounds with better steric properties to fit the binding cavity. Figure 2 represents both the binding cavity of the $3 E M L A_{2 A} A R$ and the binding mode of compounds 7 and 16 as molecular surfaces for comparison. From this figure, it is possible to observe the different occupancy of the 8-bromo-

\begin{tabular}{|c|c|c|c|c|c|c|}
\hline \multirow[t]{2}{*}{ Residue } & \multicolumn{6}{|c|}{$E_{\text {interact. }}\left[\mathrm{kcal} \mathrm{mol}^{-1}\right]$} \\
\hline & 5 & 14 & 8 & 17 & 12 & 20 \\
\hline Val84 & -1.13 & -1.15 & -0.57 & 0.33 & -0.90 & -1.42 \\
\hline Leu85 & 0.028 & -0.53 & -1.40 & -1.74 & 0.03 & -0.38 \\
\hline Thr88 & 0.20 & -0.07 & -0.42 & -0.69 & 0.21 & 0.01 \\
\hline Phe168 & -3.77 & -3.61 & -2.03 & -4.12 & -3.37 & -2.95 \\
\hline Met177 & -0.54 & -1.26 & -0.79 & -0.89 & -0.34 & -1.05 \\
\hline Trp246 & -0.14 & -0.67 & 1.78 & -0.33 & -0.33 & -0.89 \\
\hline Leu249 & -2.45 & -2.94 & -1.44 & -0.33 & -2.06 & -2.41 \\
\hline His250 & -0.52 & -0.76 & -0.29 & -1.30 & -0.62 & -0.97 \\
\hline Asn253 & -4.01 & -4.23 & -3.26 & -2.68 & -3.62 & -4.42 \\
\hline total & -12.33 & -15.23 & -8.41 & -11.74 & -11.01 & -14.47 \\
\hline
\end{tabular}

Table 4. Interaction energies between compounds 5, 14, 8, 17, 12 and 20 and the binding site residues located in the proximity of the 8-position of the analysed compounds. Data are related to the 4EIY $A_{2 A} A R$ structure. See the text for details.

\begin{tabular}{|lcccccc|} 
Residue & \multicolumn{7}{c|}{$E_{\text {interact. }}\left[\mathrm{kcal} \mathrm{mol}^{-1}\right]$} \\
& $\mathbf{5}$ & $\mathbf{1 4}$ & $\mathbf{8}$ & $\mathbf{1 7}$ & $\mathbf{1 2}$ & $\mathbf{2 0}$ \\
\hline Val84 & -0.73 & -0.38 & -0.29 & -0.2 & -0.31 & -0.22 \\
Leu85 & -0.29 & -1.36 & -1 & -1.39 & -0.95 & -1.29 \\
Thr88 & -0.01 & -0.79 & -0.6 & -0.78 & -0.6 & -0.81 \\
Phe168 & -2.58 & -3.88 & -2.17 & -3.87 & -3.2 & -4.19 \\
Met177 & -0.61 & -0.08 & -1.33 & 0.16 & -0.35 & -0.14 \\
Trp246 & -0.49 & -0.62 & -0.23 & -0.73 & -0.21 & -0.54 \\
Leu249 & -2.24 & 0.01 & -1.17 & -0.67 & -1.54 & -0.85 \\
His250 & -0.07 & -0.41 & -0.17 & -0.39 & -0.12 & -0.36 \\
Asn253 & -2.52 & -4.02 & -2.88 & -3.99 & -2.6 & -3.26 \\
total & -9.54 & -11.53 & -9.84 & -11.86 & -9.88 & -11.66 \\
\hline
\end{tabular}

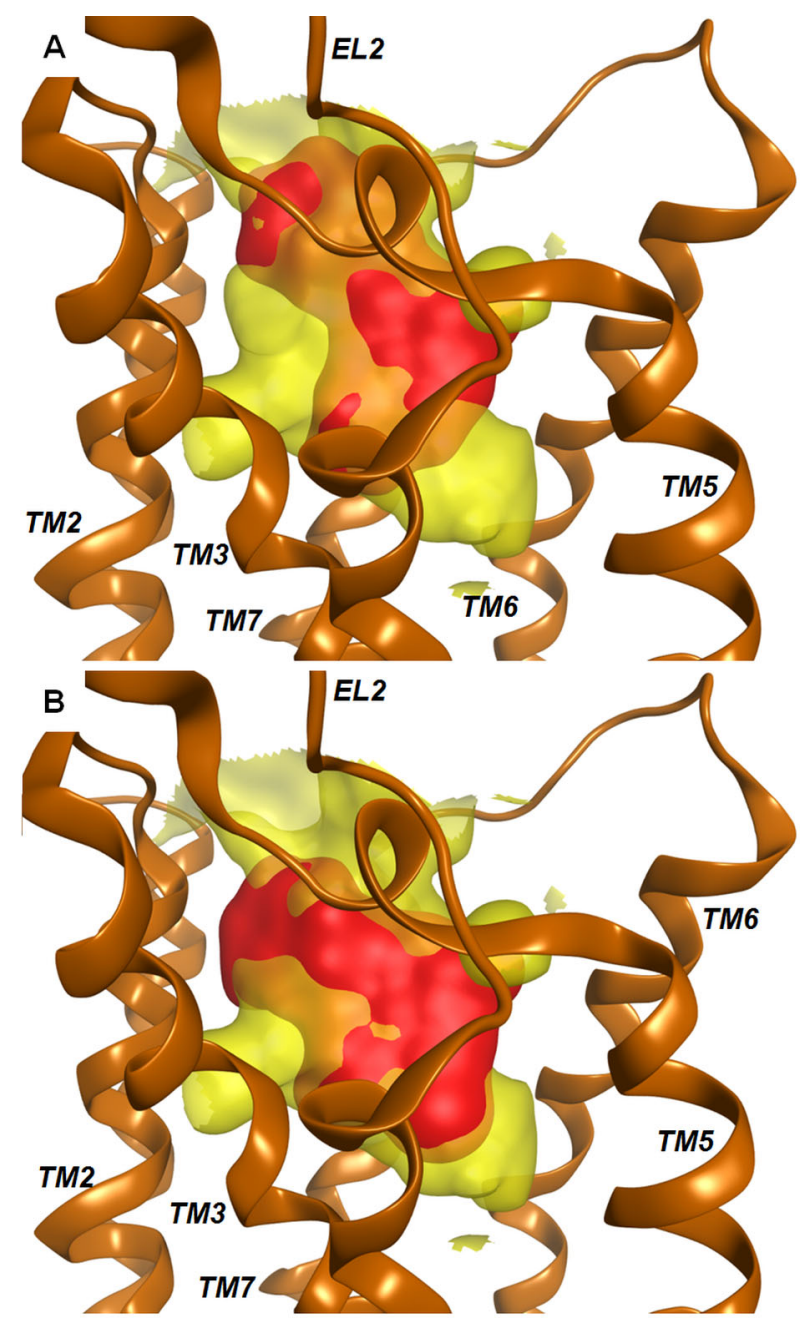

Figure 2. Docking conformations of analysed compounds at the $A_{2 A} A R$. Binding modes of compounds $7(A)$ and 16 (B), with representations as molecular surfaces; the cavity and ligand surfaces are represented as yellow and red, respectively.

substituted derivative 16 relative to the unsubstituted analogue 7, in particular in the sub-cavity created by the TM3, TM5 and TM6 residues. 
The selectivity of the synthesised molecules appears not to be very high, particularly versus the $A_{1} A R$. We therefore performed a docking analysis of a selected group of ligands (17 and 18, which present 23 and $58 \mathrm{nM} \mathrm{A}_{1}$ AR affinity, respectively) with a homology model of this receptor built by using the 4 EIY $A_{2 A}$ AR crystal structure as a template. The results of this analysis present the compounds inserted in the receptor cavity with a similar binding mode to the one retrieved at the $A_{2 A} A R$ (Figure 3 ). The residues involved in the interaction with the li-

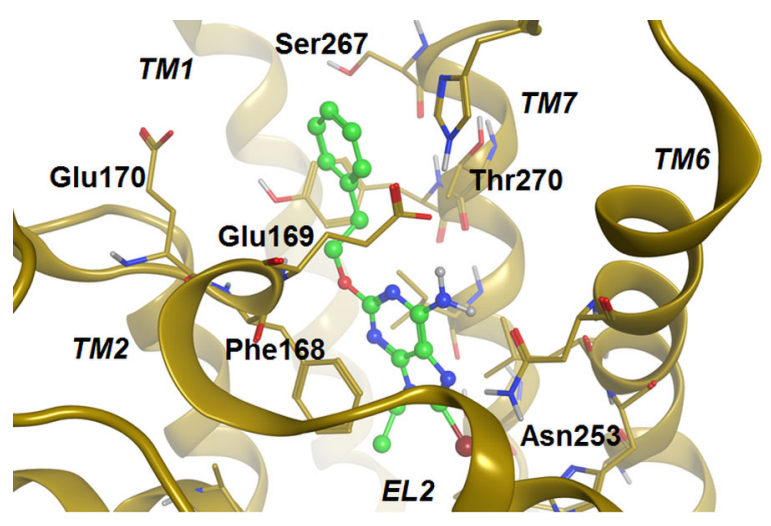

Figure 3. Docking conformation of compound $\mathbf{1 7}$ at the $A_{1} A R$ receptor model with detail of the receptor residues located at the entrance of the binding cavity.

gands are quite conserved between the $A_{1} A R$ and the $A_{2 A} A R$, particularly within the binding cavity. Some differences are observed with regard to the residues at the entrance of the cavity and in the proximity of the 2-substituent. In detail, the three hydrophobic amino acids of the $A_{2 A} A R$, Leu167 (EL2), Leu267 (EL3) and Met270 (TM7), are substituted in the $A_{1} A R$ by the polar residues Glu170 (EL2), Ser267 (EL3) and Thr270 (TM7), respectively. Hence, in the case of the compounds presenting a short 2-substituent, the chemical-physical profile of the receptor residues located in the proximity of this group appears to be significant. By contrast, the compounds presenting a long 2-substituent (and endowed in general with low AR affinity) may more easily adapt their conformation, even to the $A_{1} A R$, and optimise their interaction with the surrounding residues. This would explain the reduced (or non-existent) $A_{2 A} A R$ selectivity of the compounds presenting a propyl spacer within the 2-substituent. More data are needed to confirm this hypothesis, because in the case of the 2-thio-substituted compounds it appears that the shorter chain causes a slight preference for the $A_{1} A R$.

\section{Conclusions}

This work describes a series of 2-substituted 9-ethyladenine derivatives and their corresponding 8-bromo-substituted analogues, designed and synthesised as novel AR ligands with the aim to obtain high affinity and selectivity, in particular for the $A_{2 A}$ AR subtype. They present phenylalkyloxy, phenylalkylamino or phenylalkylthio groups of different lengths at the 2-position.
The compounds were tested with human $A R s$ in a radioligand binding assay $\left(A_{1}, A_{2 A}\right.$ and $A_{3}$ AR subtypes) and evaluated for their ability to modulate the adenylyl cyclase activity $\left(A_{2 B} A R s\right)$. The results show that the derivatives are endowed with nanomolar affinity for the ARs. This activity is higher if the alkyl spacer within the 2-substituent is one or two carbon atoms long and if the additional 8-bromo substituent is present. The 2-arylalkyloxy-substituted compounds present generally higher affinity than the corresponding 2-arylalkylamino- or 2-arylalkylthio-substituted analogues. Although the already reported compound 8-bromo-9-ethyl-2-phenylethyloxyadenine (17) remains the antagonist endowed with the highest affinity for the $A_{2 A}$ AR subtype, it should be noted that one of the newly synthesised derivatives presents low nanomolar $A_{2 A} A R$ affinity and improved selectivity versus the $A_{1} A R$ subtype (16: $K_{i} A_{2 A}=$ $6.8 \mathrm{~nm} ; A_{1} / A_{2 a}=21 ;$ versus $\left.17: K_{i} A_{2 A}=1.7 n M ; A_{1} / A_{2 a}=14\right)$. Functional studies, performed with representative molecules, confirmed that the new compounds behave as antagonists of the human $A_{2 A} A R$ with $I C_{50}$ values in the nanomolar range, in agreement with the binding data. Molecular modelling studies were performed to provide an interpretation of the different affinities of the compounds at the $A_{2 A} A R$, with particular consideration of the roles of the substituents introduced on the adenine moiety. The results highlight that the presence of the 8-bromo substituent helps the ligands to fit the receptor cavity with higher topological complementarity than the 8-unsubstituted derivatives. These data suggest that the modulation of the 8-substituent volume would further optimise the ligandreceptor interaction. In this sense, the 8-bromine atom present in these derivatives allows an easy substitution by other moieties or functional groups. Furthermore, the different lengths of the 2-substituent leads to various affinities for the $A_{2 A} A R$. In this sense, the compounds presenting longer 2-substituent chains would make the phenyl ring of this substituent more externally exposed causing an unfavourable interaction with the solvent. Further optimisation of these derivatives could lead to the modulation of the 2-substituent length combined with the modification of the phenyl ring or the insertion of polar groups at this moiety. This work makes available novel data that are useful for the design and synthesis of $A_{2 A} A R$ ligands based on the adenine scaffold and containing arylalkyl chains in the 2-position, with possible combination with further substituents in the 8-position.

\section{Experimental Section}

\section{Chemistry}

General: Melting points were determined with a Büchi apparatus and are uncorrected. ${ }^{1} \mathrm{H}$ NMR spectra were obtained with a Varian Mercury $400 \mathrm{MHz}$ spectrometer; $\delta$ values are in ppm, $J$ values are in $\mathrm{Hz}$. All exchangeable protons were confirmed by the addition of $\mathrm{D}_{2} \mathrm{O}$. Thin-layer chromatography (TLC) was carried out on precoated TLC plates with silica gel $60 \mathrm{~F}_{254}$ (Fluka). For column chromatography, silica gel 60 (Merck) was used. Elemental analyses were determined on a Fisons Instruments Model EA 1108 CHNS-O model analyser and are within $0.4 \%$ of theoretical values. The 
purity of the compounds was $\geq 95 \%$ according to the elemental analysis data.

General procedure for the synthesis of the 9-ethyl-2-phenylalkylaminoadenine derivatives 4 and 6: 2-Chloro-9-ethyladenine $(3 ; 200 \mathrm{mg}, 1.0 \mathrm{mmol})$ and the suitable amine $(3.5 \mathrm{~mL})$ were placed in a steel vial and heated at $130^{\circ} \mathrm{C}$ for $24-28 \mathrm{~h}$ until completion of the reaction. The volatiles were then removed in vacuo and the residue was subjected to chromatography on a silica gel column with elution with the suitable solvent system to obtain compounds 4 and 6 as white solids.

$N^{2}$-Benzyl-9-ethyl-9H-purine-2,6-diamine (4): Obtained by the reaction of $\mathbf{3}$ with benzylamine in a $28 \mathrm{~h}$ reaction time and by purification with normal column chromatography with elution with $\mathrm{CHCl}_{3} / \mathrm{CH}_{3} \mathrm{OH} \quad(95: 5)$; yield $65 \%$; mp: $169-173{ }^{\circ} \mathrm{C}$; ${ }^{1} \mathrm{H} \mathrm{NMR}$ ([D $\left.\left.\mathrm{D}_{6}\right] \mathrm{DMSO}\right): \delta=1.31\left(\mathrm{t}, 3 \mathrm{H}, J=7.2 \mathrm{~Hz}, \mathrm{CH}_{2} \mathrm{CH}_{3}\right), 3.97(\mathrm{~m}, 2 \mathrm{H}$, $\left.\mathrm{CH}_{2} \mathrm{NH}\right), 4.48\left(\mathrm{q}, 2 \mathrm{H}, J=7.2 \mathrm{~Hz}, \mathrm{CH}_{2} \mathrm{CH}_{3}\right), 6.65\left(\mathrm{brs}, 2 \mathrm{H}, \mathrm{NH}_{2}\right), 6.79(\mathrm{t}$, $2 \mathrm{H}, J=5.6 \mathrm{~Hz}, \mathrm{NH}), 7.14-7.37(\mathrm{~m}, 5 \mathrm{H}, \mathrm{HPh}), 7.71 \mathrm{ppm}(\mathrm{s}, 1 \mathrm{H}, \mathrm{H} 8)$; elemental analysis: calcd for $\mathrm{C}_{14} \mathrm{H}_{16} \mathrm{~N}_{6}: \mathrm{C} 62.67, \mathrm{H}$ 6.01, N 31.32, found: C 62.78, H 6.16, N 31.21 .

9-Ethyl- $\mathrm{N}^{2}$-(3-phenylpropyl)-9H-purine-2,6-diamine (6): Obtained by the reaction of 3 with 1-propylamine in a $24 \mathrm{~h}$ reaction time and by purification with flash column chromatography with elution with $\mathrm{CHCl}_{3} / \mathrm{CH}_{3} \mathrm{OH}$ (98:2); yield $70 \%$; $\mathrm{mp}: 65-70^{\circ} \mathrm{C}$; ${ }^{1} \mathrm{H} \mathrm{NMR}$ ([D $\left.\left.\mathrm{D}_{6}\right] \mathrm{DMSO}\right): \delta=1.35\left(\mathrm{t}, 3 \mathrm{H}, J=7.2 \mathrm{~Hz}, \mathrm{CH}_{2} \mathrm{CH}_{3}\right), 1.83(\mathrm{~m}, 2 \mathrm{H}$, $\left.\mathrm{CH}_{2} \mathrm{CH}_{2} \mathrm{CH}_{2}\right), 2.64\left(\mathrm{t}, 2 \mathrm{H}, J=7.2 \mathrm{~Hz}, \mathrm{CH}_{2} \mathrm{Ph}\right), 3.27\left(\mathrm{~m}, 2 \mathrm{H}, \mathrm{CH}_{2} \mathrm{NH}\right)$, $3.99\left(\mathrm{q}, 2 \mathrm{H}, J=7.2 \mathrm{~Hz}, \mathrm{CH}_{2} \mathrm{CH}_{3}\right), 6.30(\mathrm{t}, 1 \mathrm{H}, J=5.6 \mathrm{~Hz}, \mathrm{NH}), 6.59$ (brs, $\left.2 \mathrm{H}, \mathrm{NH}_{2}\right), 7.25(\mathrm{~m}, 5 \mathrm{H}, \mathrm{HPh}), 7.71 \mathrm{ppm}(\mathrm{s}, 1 \mathrm{H}, \mathrm{H} 8)$; elemental analysis: calcd for $\mathrm{C}_{16} \mathrm{H}_{20} \mathrm{~N}_{6}$ : C 64.84, $\mathrm{H}$ 6.80, $\mathrm{N} 28.36$, found: $\mathrm{C}$ 64.97, H 6.87, N 28.29.

General procedure for the synthesis of the 9-ethyl-2-phenylalkoxyadenine derivatives 7 and 9: Anhydrous $\mathrm{NaOH}(200 \mathrm{mg}$, $5 \mathrm{mmol}$ ) was added to a mixture of 2-chloro-9-ethyladenine (3) $(200 \mathrm{mg}, 1.0 \mathrm{mmol})$ suspended in the suitable alcohol $(9.0 \mathrm{~mL})$. The mixture was heated at $85-105^{\circ} \mathrm{C}$ for $3-4 \mathrm{~h}$. The solvent was then removed in vacuo and the residue was suspended in $\mathrm{H}_{2} \mathrm{O}$, neutralised with $2 \mathrm{~N} \mathrm{HCl}$ and then partitioned with $\mathrm{CHCl}_{3}$ three times. The combined organic layers were dried over anhydrous $\mathrm{Na}_{2} \mathrm{SO}_{4}$, filtered and concentrated in vacuo. Compounds 7 and 9 were obtained after purification with silica gel flash column chromatography with elution with the appropriate solvent system.

2-Benzyloxy-9-ethyl-9H-purin-6-amine (7): Obtained by reaction of 3 with benzyl alcohol in a $4 \mathrm{~h}$ reaction time and by column chromatography with elution with $\mathrm{CHCl}_{3} / \mathrm{CH}_{3} \mathrm{OH}$ (95:5); yield 49\%; white solid (cryst. $\mathrm{CH}_{3} \mathrm{OH}$ ); $\mathrm{mp}$ : $168-170^{\circ} \mathrm{C}$; ${ }^{1} \mathrm{H}$ NMR ([D $\left.\left.\mathrm{D}_{6}\right] \mathrm{DMSO}\right)$ : $\delta=1.37\left(\mathrm{t}, 3 \mathrm{H}, J=7.2 \mathrm{~Hz}, \mathrm{CH}_{3}\right), 4.08\left(\mathrm{q}, 2 \mathrm{H}, J=7.2 \mathrm{~Hz}, \mathrm{CH}_{2} \mathrm{CH}_{3}\right), 5.32$ $\left(\mathrm{s}, 2 \mathrm{H}, \mathrm{OCH}_{2} \mathrm{Ph}\right), 7.25\left(\mathrm{~s}, 2 \mathrm{H}, \mathrm{NH}_{2}\right), 7.34-7.50(\mathrm{~m}, 5 \mathrm{H}, \mathrm{HPh})$, $7.98 \mathrm{ppm}(\mathrm{s}, 1 \mathrm{H}, \mathrm{H} 8)$; elemental analysis: calcd for $\mathrm{C}_{14} \mathrm{H}_{15} \mathrm{~N}_{5} \mathrm{O}$ : C 62.44, H 5.61, N 26.01, found: C 62.57, H 5.71, N 25.92.

9-Ethyl-2-(3-phenylpropoxy)-9H-purin-6-amine (9): Obtained by the reaction of 3 with 1-propylalcohol in a $4 \mathrm{~h}$ reaction time and by column chromatography with elution with $\mathrm{CHCl}_{3} / \mathrm{CH}_{3} \mathrm{OH}$ (95:5); yield $83 \%$; white solid (cryst. $\mathrm{CH}_{3} \mathrm{CN}$ ); $\mathrm{mp}$ : $131-133{ }^{\circ} \mathrm{C}$; ${ }^{1} \mathrm{H}$ NMR ([D $\left.\left.\mathrm{D}_{6}\right] \mathrm{DMSO}\right): \delta=1.38\left(\mathrm{t}, 3 \mathrm{H}, J=7.2 \mathrm{~Hz}, \mathrm{CH}_{3}\right), 2.00\left(\mathrm{~m}, 2 \mathrm{H}, \mathrm{CH}_{2} \mathrm{CH}_{2} \mathrm{O}\right)$, $2.74\left(\mathrm{t}, 2 \mathrm{H}, J=7.06 \mathrm{~Hz}, \mathrm{CH}_{2} \mathrm{Ph}\right), 4.07\left(\mathrm{q}, 2 \mathrm{H}, J=7.2 \mathrm{~Hz}, \mathrm{CH}_{2} \mathrm{CH}_{3}\right)$, $4.22\left(\mathrm{t}, 2 \mathrm{H}, J=6.4 \mathrm{~Hz}, \mathrm{CH}_{2} \mathrm{O}\right), 7.13-7.37\left(\mathrm{~m}, 7 \mathrm{H}, \mathrm{HPh}\right.$ and $\left.\mathrm{NH}_{2}\right)$, $7.96 \mathrm{ppm}(\mathrm{s}, 1 \mathrm{H}, \mathrm{H} 8)$; elemental analysis: calcd for $\mathrm{C}_{16} \mathrm{H}_{19} \mathrm{~N}_{5} \mathrm{O}$ : C 64.63, H 6.44, N 23.55, found: C 64.68, H 6.55, N 23.43.

General procedure for the synthesis of the 9-ethyl-2-phenylalkylthioadenine derivatives 11 and 12: A suspension of 2-iodo-9ethyladenine $(10 ; 289 \mathrm{mg}, 1.0 \mathrm{mmol})$ in the suitable thiol $(5.8 \mathrm{~mL})$ and anhydrous $\mathrm{NaOH}(280 \mathrm{mg})$ was placed in a steel vial in an oven at $100^{\circ} \mathrm{C}$ for $24 \mathrm{~h}$. The volatiles were then removed in vacuo and the residue was suspended in $\mathrm{H}_{2} \mathrm{O}$, neutralised with $1 \mathrm{~N} \mathrm{HCl}$ and partitioned three times with $\mathrm{CHCl}_{3}$. The collected organic layers were dried over anhydrous $\mathrm{Na}_{2} \mathrm{SO}_{4}$, filtered and concentrated in vacuo. Compounds 11 and $\mathbf{1 2}$ were obtained as white solids after silica gel normal column chromatography with elution with $\mathrm{CHCl}_{3} / \mathrm{CH}_{3} \mathrm{OH}$ (97:3).

2-(Benzylthio)-9-ethyl-9H-purin-6-amine (11): Obtained by the reaction of 10 with benzylthiol; yield $65 \%$; $\mathrm{mp}: 145-147^{\circ} \mathrm{C}$; ${ }^{1} \mathrm{H}$ NMR ([D $\left.\left.\mathrm{D}_{6}\right] \mathrm{DMSO}\right): \delta=1.39\left(\mathrm{t}, 3 \mathrm{H}, J=7.2 \mathrm{~Hz}, \mathrm{CH}_{2} \mathrm{CH}_{3}\right), 4.14(\mathrm{q}, 2 \mathrm{H}, J=$ $\left.7.2 \mathrm{~Hz}, \mathrm{CH}_{2} \mathrm{CH}_{3}\right), 4.36\left(\mathrm{~s}, 2 \mathrm{H}, \mathrm{CH}_{2} \mathrm{Ph}\right), 7.19-7.44(\mathrm{~m}, 7 \mathrm{H}, \mathrm{HPh}$ and $\left.\mathrm{NH}_{2}\right), 8.04 \mathrm{ppm}(\mathrm{s}, 1 \mathrm{H}, \mathrm{H} 8)$; elemental analysis: calcd for $\mathrm{C}_{14} \mathrm{H}_{15} \mathrm{~N}_{5} \mathrm{~S}$ : C 58.93, H 5.30, N 24.54, found: C 59.04, H 5.35, N 24.49.

9-Ethyl-2-(phenethylthio)-9H-purin-6-amine (12): Obtained by the reaction of 10 with 2-phenethylthiol; yield $77 \%$; $\mathrm{mp}: 152-154^{\circ} \mathrm{C}$; ${ }^{1} \mathrm{H}$ NMR ([D $\left.\left.\mathrm{D}_{6}\right] \mathrm{DMSO}\right): \delta=1.42\left(\mathrm{t}, 3 \mathrm{H}, J=7.2 \mathrm{~Hz}, \mathrm{CH}_{2} \mathrm{CH}_{3}\right), 3.00(\mathrm{~m}$, $\left.2 \mathrm{H}, \mathrm{CH}_{2} \mathrm{Ph}\right), 3.31\left(\mathrm{~m}, 2 \mathrm{H}, \mathrm{CH}_{2} \mathrm{~S}\right), 4.16\left(\mathrm{q}, 2 \mathrm{H}, J=7.2 \mathrm{~Hz}, \mathrm{CH}_{2} \mathrm{CH}_{3}\right)$, 7.19-7.24 (m, 7H, HPh and $\left.\mathrm{NH}_{2}\right), 8.05 \mathrm{ppm}(\mathrm{s}, 1 \mathrm{H}, \mathrm{H} 8)$; elemental analysis: calcd for $\mathrm{C}_{15} \mathrm{H}_{17} \mathrm{~N}_{5} \mathrm{~S}$ : C 60.18, H 5.72, N 23.39, found: $\mathrm{C}$ 60.29, H 5.83, N 23.30.

General procedure for the synthesis of the 8-bromo-9-ethyl-2substituted adenine derivatives 13-18: NBS (267 mg, $1.5 \mathrm{mmol})$ was added to a solution of either 4-9, 11 or $12(1.0 \mathrm{mmol})$ in anhydrous DMF $(10 \mathrm{~mL})$. The mixture was left under stirring at room temperature for 20-50 min. The solvent was then removed in vacuo and the residue was purified on silica gel normal column chromatography with elution with the suitable eluent to obtain the pure desired products as white solids.

$\mathrm{N}^{2}$-Benzyl-8-bromo-9-ethyl-9H-purine-2,6-diamine (13): Obtained from 4; purified by silica gel normal column chromatography with elution with $\mathrm{CHCl}_{3} / \mathrm{CH}_{3} \mathrm{OH}$ (98:2); yield $19 \%$; $\mathrm{mp}$ : $156-158^{\circ} \mathrm{C}$; ${ }^{1} \mathrm{H}$ NMR ([D $]$ ]DMSO): $\delta=1.25\left(\mathrm{t}, 3 \mathrm{H}, J=7.3 \mathrm{~Hz}, \mathrm{CH}_{2} \mathrm{CH}_{3}\right), 3.99(\mathrm{q}, 2 \mathrm{H}$, $\left.J=7.3 \mathrm{~Hz}, \mathrm{CH}_{2} \mathrm{CH}_{3}\right), 4.47\left(\mathrm{~d}, 2 \mathrm{H}, J=6.5 \mathrm{~Hz}, \mathrm{NHCH}_{2}\right.$ ), 6.82 (brs, $2 \mathrm{H}$, $\left.\mathrm{NH}_{2}\right), 6.98\left(\mathrm{t}, 1 \mathrm{H}, J=6.5 \mathrm{~Hz}, \mathrm{NHCH}_{2}\right), 7.13-7.40 \mathrm{ppm}(\mathrm{m}, 5 \mathrm{H}, \mathrm{HPh})$; elemental analysis: calcd for $\mathrm{C}_{14} \mathrm{H}_{15} \mathrm{BrN}_{6}$ : C 48.43, H 4.35, N 24.20, found: C 48.52, H 4.44, N 24.13.

8-Bromo-9-ethyl- $\mathrm{N}^{2}$-phenethyl-9H-purine-2,6-diamine (14): Obtained from 5; purified by silica gel normal column chromatography with elution with EtOAc/ $\mathrm{C}_{6} \mathrm{H}_{12} / \mathrm{CH}_{3} \mathrm{OH}$ (60:39:1); yield $62 \%$ (cryst. $\left.\mathrm{CH}_{3} \mathrm{CN} / \mathrm{CH}_{3} \mathrm{OH}\right) ; \mathrm{mp}: 182-183^{\circ} \mathrm{C}$; ${ }^{1} \mathrm{H}$ NMR ([D 6 ]DMSO): $\delta=$ $1.30\left(\mathrm{t}, 3 \mathrm{H}, J=7.2 \mathrm{~Hz}, \mathrm{CH}_{2} \mathrm{CH}_{3}\right), 2.84\left(\mathrm{t}, 2 \mathrm{H}, J=7.5 \mathrm{~Hz}, \mathrm{NHCH}_{2}\right), 3.45$ $\left(\mathrm{m}, 2 \mathrm{H}, \mathrm{CH}_{2} \mathrm{Ph}\right), 4.02\left(\mathrm{q}, 2 \mathrm{H}, J=7.2 \mathrm{~Hz}, \mathrm{CH}_{2} \mathrm{CH}_{3}\right), 6.45(\mathrm{~m}, 1 \mathrm{H}$, $\left.\mathrm{NHCH}_{2}\right), 6.58$ (brs, $\left.2 \mathrm{H}, \mathrm{NH}_{2}\right), 7.28 \mathrm{ppm}(\mathrm{m}, 5 \mathrm{H}, \mathrm{HPh})$ elemental analysis: calcd for $\mathrm{C}_{15} \mathrm{H}_{17} \mathrm{BrN}_{6}$ : C 49.87, H 4.74, N 23.26, found: $\mathrm{C}$ 49.99, H 4.76, N 23.19.

8-Bromo-9-ethyl- $\mathrm{N}^{2}$-(3-phenylpropyl)-9H-purine-2,6-diamine (15): Obtained from 6; purified by silica gel normal column chromatography with elution with $\mathrm{cHex} / \mathrm{EtOAC} / \mathrm{CH}_{3} \mathrm{OH}$ (70:29:1); yield $54 \%$

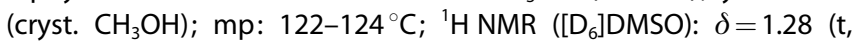
$\left.3 \mathrm{H}, J=7.2 \mathrm{~Hz}, \mathrm{CH}_{2} \mathrm{CH}_{3}\right), 1.83\left(\mathrm{~m}, 2 \mathrm{H}, \mathrm{CH}_{2} \mathrm{CH}_{2} \mathrm{CH}_{2}\right), 2.64(\mathrm{t}, 2 \mathrm{H}, J=$ $\left.7.2 \mathrm{~Hz}, \mathrm{CH}_{2} \mathrm{Ph}\right), 3.27\left(\mathrm{~m}, 2 \mathrm{H}, \mathrm{CH}_{2} \mathrm{NH}\right), 4.00(\mathrm{q}, 2 \mathrm{H}, J=7.2 \mathrm{~Hz}$, $\left.\mathrm{CH}_{2} \mathrm{CH}_{3}\right), 6.49(\mathrm{t}, 1 \mathrm{H}, J=7.8 \mathrm{~Hz}, \mathrm{NH}), 6.80\left(\mathrm{brs}, 2 \mathrm{H}, \mathrm{NH}_{2}\right), 7.24 \mathrm{ppm}$ (m, $5 \mathrm{H}, \mathrm{HPh}$ ); elemental analysis: calcd for $\mathrm{C}_{16} \mathrm{H}_{19} \mathrm{BrN}_{6}: \mathrm{C} 51.21, \mathrm{H}$ 5.10, N 22.39, found: C 51.29, H 5.17, N 22.30.

2-(Benzyloxy)-8-bromo-9-ethyl-9H-purin-6-amine (16): Obtained from 7 with a 20 min reaction time; purified by silica gel flash column chromatography with elution with $\mathrm{cHex} / \mathrm{CHCl}_{3} / \mathrm{CH}_{3} \mathrm{OH}$ (59:40:1); yield $66 \%$ (cryst. $\mathrm{CHCl}_{3}$ ); $\mathrm{mp}: 208-210^{\circ} \mathrm{C}$; ${ }^{1} \mathrm{H}$ NMR ([D $\left.\left.\mathrm{D}_{6}\right] \mathrm{DMSO}\right): \delta=1.30\left(\mathrm{t}, 3 \mathrm{H}, J=7.0 \mathrm{~Hz}, \mathrm{CH}_{3}\right), 4.08(\mathrm{q}, 2 \mathrm{H}, J=7.0 \mathrm{~Hz}$, 
$\left.\mathrm{CH}_{2} \mathrm{CH}_{3}\right), 5.32\left(\mathrm{~s}, 2 \mathrm{H}, \mathrm{CH}_{2} \mathrm{Ph}\right), 7.30-750 \mathrm{ppm}\left(\mathrm{m}, 7 \mathrm{H}, \mathrm{HPh}\right.$ and $\left.\mathrm{NH}_{2}\right)$; elemental analysis: calcd for $\mathrm{C}_{14} \mathrm{H}_{14} \mathrm{BrN}_{5} \mathrm{O}: \mathrm{C} 48.29, \mathrm{H} 4.05, \mathrm{~N} 20.11$, found: C 48.34, H 4.11, N 20.09.

8-Bromo-9-ethyl-2-phenethoxy-9H-purin-6-amine (17): Obtained from 8 with a 45 min reaction time; purified by silica gel flash column chromatography with elution with $\mathrm{EtOAc} / \mathrm{cHex} / \mathrm{CH}_{3} \mathrm{OH}$ (50:49:1); yield $56 \%$ (cryst. $\mathrm{CH}_{3} \mathrm{CN} / \mathrm{CH}_{3} \mathrm{OH}$ ); $\mathrm{mp}$ : $169-171^{\circ} \mathrm{C}$; ${ }^{1} \mathrm{H}$ NMR ([D $]$ DMSO): $\delta=1.28\left(\mathrm{t}, 3 \mathrm{H}, J=7.0 \mathrm{~Hz}, \mathrm{CH}_{2} \mathrm{CH}_{3}\right), 2.99(\mathrm{t}, 2 \mathrm{H}$, $\left.J=7.0 \mathrm{~Hz}, \mathrm{CH}_{2} \mathrm{NH}\right), 4.04\left(\mathrm{q}, 2 \mathrm{H}, J=7.0 \mathrm{~Hz}, \mathrm{CH}_{2} \mathrm{CH}_{3}\right), 4.39(\mathrm{t}, 2 \mathrm{H}, J=$ $7.0 \mathrm{~Hz}, \mathrm{CH}_{2} \mathrm{O}$ ), 7.25-7.32 (m, 5 H, HPh), 7.37 ppm (brs, $\left.2 \mathrm{H}, \mathrm{NH}_{2}\right)$; elemental analysis: calcd for $\mathrm{C}_{15} \mathrm{H}_{16} \mathrm{BrN}_{5} \mathrm{O}: \mathrm{C} 49.74, \mathrm{H} \mathrm{4.45,} \mathrm{N} \mathrm{19.33,}$ found: C 49.80, H 4.48, N 19.31.

8-Bromo-9-ethyl-2-(3-phenylpropoxy)-9H-purin-6-amine (18): Obtained from 9 with a 20 min reaction time; purified by silica gel flash column chromatography with elution with $\mathrm{cHex} / \mathrm{CHCl}_{3} /$ $\mathrm{CH}_{3} \mathrm{OH}$ (59:40:1); yield 69\% (cryst. $\mathrm{CH}_{3} \mathrm{CN}$ ); mp: 181-183 ${ }^{\circ} \mathrm{C}$; ${ }^{1} \mathrm{H}$ NMR ([D $\left.\left.\mathrm{D}_{6}\right] \mathrm{DMSO}\right): \delta=1.30\left(\mathrm{t}, 3 \mathrm{H}, J=7.2 \mathrm{~Hz}, \mathrm{CH}_{3}\right), 2.00(\mathrm{~m}, 2 \mathrm{H}$, $\left.\mathrm{CH}_{2} \mathrm{CH}_{2} \mathrm{O}\right), 2.73\left(\mathrm{t}, 2 \mathrm{H}, J=7.0 \mathrm{~Hz}, \mathrm{CH}_{2} \mathrm{Ph}\right), 4.06(\mathrm{q}, 2 \mathrm{H}, J=7.2 \mathrm{~Hz}$, $\left.\mathrm{CH}_{2} \mathrm{CH}_{3}\right), 4.22\left(\mathrm{t}, 2 \mathrm{H}, J=6.5 \mathrm{~Hz}, \mathrm{CH}_{2} \mathrm{O}\right), 7.15-7.35(\mathrm{~m}, 5 \mathrm{H}, \mathrm{HPh})$, $7.38 \mathrm{ppm}$ (brs, $2 \mathrm{H}, \mathrm{NH}_{2}$ ); elemental analysis: calcd for $\mathrm{C}_{16} \mathrm{H}_{18} \mathrm{BrN}_{5} \mathrm{O}$ : C 51.08, H 4.82, N 18.61, found: C 51.13, H 4.89, N 18.58 .

2-(Benzylthio)-8-bromo-9-ethyl-9H-purin-6-amine (19): Obtained from 11 with a 50 min reaction time; purified by silica gel preparative TLC with elution with $\mathrm{C}_{6} \mathrm{H}_{12} / \mathrm{EtOAc} / \mathrm{CH}_{3} \mathrm{OH}$ (59:40:1); yield $8 \%$; $\mathrm{mp}$ : not determined because a vitreous solid; ${ }^{1} \mathrm{H}$ NMR ( $\left.\left[\mathrm{D}_{6}\right] \mathrm{DMSO}\right)$ : $\delta=1.31\left(\mathrm{t}, 3 \mathrm{H}, J=7.2 \mathrm{~Hz}, \mathrm{CH}_{2} \mathrm{CH}_{3}\right), 4.14\left(\mathrm{q}, 2 \mathrm{H}, J=7.2 \mathrm{~Hz}, \mathrm{CH}_{2} \mathrm{CH}_{3}\right)$, $4.36\left(\mathrm{~s}, 2 \mathrm{H}, \mathrm{CH}_{2} \mathrm{Ph}\right), 7.19-7.59 \mathrm{ppm}\left(\mathrm{m}, 7 \mathrm{H}, \mathrm{HPh}\right.$ and $\left.\mathrm{NH}_{2}\right)$; elemental analysis: calcd for $\mathrm{C}_{14} \mathrm{H}_{14} \mathrm{BrN}_{5} \mathrm{~S}$ : C 46.16, H 3.87, N 19.23, found: C 46.68, H 3.95, N 19.17.

8-Bromo-9-ethyl-2-(phenethylthio)-9H-purin-6-amine (20): Obtained from 12 with a 40 min reaction time; purified by silica gel preparative TLC with elution with EtOAc/ $\mathrm{C}_{6} \mathrm{H}_{12} / \mathrm{CH}_{3} \mathrm{OH}$ (60:35:5); yield $18 \%$; mp: $124-126^{\circ} \mathrm{C} ;{ }^{1} \mathrm{H}$ NMR ( $\left.\left[\mathrm{D}_{6}\right] \mathrm{DMSO}\right): \delta=1.34(\mathrm{t}, 3 \mathrm{H}, J=$ $\left.7.2 \mathrm{~Hz}, \mathrm{CH}_{2} \mathrm{CH}_{3}\right), 2.98\left(\mathrm{~m}, 2 \mathrm{H}, \mathrm{CH}_{2} \mathrm{~S}\right), 3.29\left(\mathrm{~m}, 2 \mathrm{H}, \mathrm{CH}_{2} \mathrm{Ph}\right), 4.14$ (q, $\left.2 \mathrm{H}, J=7.2 \mathrm{~Hz}, \mathrm{CH}_{2} \mathrm{CH}_{3}\right), 7.19-7.33(\mathrm{~m}, 5 \mathrm{H}, \mathrm{HPh}), 7.47 \mathrm{ppm}$ (brs, $2 \mathrm{H}$, $\mathrm{NH}_{2}$ ); elemental analysis: calcd for $\mathrm{C}_{15} \mathrm{H}_{16} \mathrm{BrN}_{5} \mathrm{~S}$ : C 47.63, H 4.26, N 18.51, found: C 47.75, H 4.56, N 18.41 .

\section{Biological assays}

Radioligand binding studies: The binding studies were performed by following the procedures described earlier. ${ }^{[9]}$ In brief, membranes for radioligand binding were prepared from $\mathrm{CHO}$ cells stably transfected with human adenosine receptor subtypes in a two-step procedure. In a first low-speed step $(1000 \times \mathrm{g})$, cell fragments and nuclei were removed. The crude membrane fraction was sedimented from the supernatant at $100000 \times \mathrm{g}$. The membrane pellet was resuspended in the buffer used for the respective binding experiments, frozen in liquid nitrogen and stored at $-80^{\circ} \mathrm{C}$. For the measurement of adenylyl cyclase activity, only one high-speed centrifugation of the homogenate was used. The resulting crude membrane pellet was resuspended in $50 \mathrm{~mm}$ tris(hydroxymethyl)aminomethane/ $\mathrm{HCl}, \mathrm{pH} 7.4$, and immediately used for the cyclase assay. For $A_{1} A R$ binding, $1 \mathrm{nM}\left[{ }^{3} \mathrm{H}\right] C \mathrm{CPA}$ was used as the radioligand, whereas $10 \mathrm{nM}\left[{ }^{3} \mathrm{H}\right] \mathrm{NECA}$ was used for $\mathrm{A}_{2 \mathrm{~A}} \mathrm{AR}$ and $1 \mathrm{nM}\left[{ }^{3} \mathrm{H}\right] \mathrm{HEMADO}$ for $\mathrm{A}_{3} \mathrm{~A}$ AR. Non-specific binding was determined in the presence of $1 \mathrm{~mm}$ theophylline $\left(A_{1} A R\right)$ or $100 \mu \mathrm{M}$ $\left(A_{2 A}\right.$ and $\left.A_{3} A R\right) . K_{i}$ values from competition experiments were calculated with the program SCTFIT. ${ }^{[22]}$ Radioligand binding at the $A_{2 B}$ $A R$ is problematic because no high-affinity ligand is available for this subtype. Therefore, inhibition of NECA-stimulated adenylyl cy- clase activity was determined as a measurement of affinity of the compounds. $I C_{50}$ values from these experiments were converted into $K_{\mathrm{i}}$ values with the Cheng and Prusoff equation. ${ }^{[23]}$

Functional assays at the $A_{2 A} A R$ : The performed GloSensor ${ }^{\mathrm{TM}}$ CAMP assay is a new non-radioactive method that offers a simple and powerful approach to monitor G-protein coupled receptor (GPCR) activity through change in the intracellular CAMP concentration. The assay uses a mutant form of Photinus pyralis luciferase into which a CAMP binding protein moiety has been inserted. The binding with CAMP triggers a biosensor conformation change that leads to an increase of light output and allows evaluation of the activity of ligands at the receptor under study. After pre-equilibration with a substrate, cells stably expressing the receptor of interest and, transiently, the biosensor can be used to evaluate the GPCR function, which enables easy kinetic measurements of CAMP accumulation or turnover in living cells.

Cell culture: $\mathrm{CHO}$ cells stably expressing human $\mathrm{A}_{2 \mathrm{~A}} \mathrm{AR}$ were grown adherently and maintained in Dulbecco's modified Eagle's medium with nutrient mixture F12 (DMEM/F12 with phenol red), supplemented with $10 \%$ fetal bovine serum (FBS), $100 \mathrm{UmL}^{-1}$ penicillin, $100 \mu \mathrm{g} \mathrm{m}^{-1}$ streptomycin, $2.5 \mu \mathrm{g} \mathrm{mL}^{-1}$ amphotericin, $1 \mathrm{~mm}$ sodium pyruvate and $0.1 \mathrm{mg} \mathrm{mL}^{-1}$ Geneticin (G418), at $37^{\circ} \mathrm{C}$ and aerated with $5 \% \mathrm{CO}_{2}: 95 \% \mathrm{O}_{2}$. Cells were grown to approximately $70-80 \%$ confluence and transient transfection with plasmid encoding the biosensor was performed.

GloSensor ${ }^{\mathrm{TM}}$ CAMP assay: Cells were harvested in $\mathrm{CO}_{2}$-independent medium and were counted in a Neubauer chamber. The desired number of cells was incubated in equilibration medium containing a $3 \% \mathrm{v} / \mathrm{v}$ GloSensor ${ }^{\mathrm{TM}}$ CAMP reagent stock solution, $10 \% \mathrm{FBS}$, and $87 \% \mathrm{CO}_{2}$ independent medium. After $2 \mathrm{~h}$ of incubation, the cells were dispensed in the wells of a 384-well plate and, when a steady-state basal signal was obtained, the NECA referent agonist or the understudy compounds, at different concentrations, were added. The new synthesised compounds did not produce stimulation of CAMP, so they were evaluated as antagonists. The antagonist profile was evaluated by assessing their ability to counteract an agonist-induced increase of cAMP accumulation. The cells were incubated in the reaction medium (10 $\mathrm{min}$ at room temperature) with different understudy molecule concentrations and then treated with NECA. After $10 \mathrm{~min}$, various luminescence reads were performed at different incubation times.

Statistical analysis: Responses were expressed as a percentage of the maximal relative luminescence units (RLU). Concentration-response curves were fitted by a nonlinear regression with the Prism 4.0 programme (GraphPAD Software, San Diego, CA, USA). To quantify the NECA agonist potency, the $\mathrm{EC}_{50}$ value was calculated. The $\mathrm{EC}_{50}$ value is the concentration of agonists required to produce $50 \%$ of the maximum effect. To evaluate the antagonist profile, the $I C_{50}$ values were determined. The $I C_{50}$ value is the concentration of antagonists that produces $50 \%$ inhibition of the agonist effect. Each concentration was tested five times in triplicate and the values are given as the mean \pm standard error.

\section{Molecular modelling}

General: Homology modelling and energy minimisation were carried out with the MOE (version 2010.10) suite. ${ }^{[14]}$ All ligand structures were optimised by using RHF/AM1 semiempirical calculations and the software package MOPAC implemented in MOE was utilised for these calculations. ${ }^{[15]}$ 
Refinement of the human $A_{2 A}$ AR structures: Two crystal structures of the human $A_{2 A} A R$ in complex with ZM241385 were retrieved from the Protein Data Bank (http://www.rcsb.org; PDB ID: 3 EML at $2.6 \AA$ resolution and PDB ID: 4 EIY at $1.8 \AA$ resolution ${ }^{[13]}$ ). The $3 E M L$ crystal structure was re-modelled firstly by removing the T4L external segment and secondly by performing a building of missing receptor regions (that is, missing sections of the EL2 or IL3 domains). The Homology Modelling tool of the MOE suite was employed. In detail, the boundaries identified from the used $A_{2 A} A R X$ ray crystal structure were applied and the missing loop domains were built by the loop search method implemented in the MOE suite. Once the heavy atoms were modelled, all hydrogen atoms were added, and the protein coordinates were then minimised with the MOE suite by using the AMBER99 force field. ${ }^{[24]}$ The minimisations were performed by steepest descent steps followed by conjugate gradient minimisation until the root mean square gradient of the potential energy was less than $0.05 \mathrm{~kJ} \mathrm{~mol}^{-1} \AA^{-1}$. The reliability and quality of the model were checked with the Protein Geometry Monitor application within the MOE suite, which provides a variety of stereochemical measurements for inspection of the structure quality in a given protein, such as backbone bond lengths, angles and dihedrals, Ramachandran $\varphi-\psi$ dihedral plots and side-chain-rotamer and non-bonded contact qualities. The 4 EIY crystal structure was used in its original form, to which all hydrogen atoms were added within the MOE suite.

Homology modelling of the human $A_{1}$ AR structure: $A$ homology model of the human $A_{1} A R$ was built by using the 4 EIY $A_{2 A}$ AR crystal structure (see above for details) as a template. A multiple alignment of the AR primary sequences was built within the MOE suite as a preliminary step. The boundaries identified from the used $X$ ray crystal structure of $A_{2 A} A R$ were then applied for the corresponding sequences of the TM helices of the $A_{1} A R$. The missing loop domains were built by the loop search method implemented in the MOE suite. Hydrogen atom addition and energy minimisation steps were made as described above for the $3 E M L A_{2 A} A R$ remodelling stage.

Molecular docking analysis: All compound structures were docked into the binding site of the $A_{2 A} A R$ by using AutoDock 4.2.6 software and the PyRx interface. ${ }^{[16]}$ The Lamarckian genetic algorithm was employed for this analysis with the following settings: 50 runs for each ligand, 2500000 as the maximum number of energy evaluations, 27000 as the maximum number of generations, 0.02 as the rate of gene mutation and 0.8 as the rate of crossover. The grid box was set with 50,50 and 50 points in the $x$, $y$ and $z$ directions, respectively, with the default grid spacing of $0.375 \AA$. This protocol was also used for the docking of a selected group of ligands at the $A_{1} A R$.

Post-docking analysis and residue interaction analysis: The interactions between the ligands and the receptor binding site were analysed by using the IF-E 6.0 tool that is retrievable at the SVL exchange service (Chemical Computing Group, Inc.; SVL exchange: svl.chemcomp.com). The program calculates and displays the atomic and residue interaction forces as $3 \mathrm{D}$ vectors. It also calculates the per-residue interaction energies, for which negative and positive energy values are associated to favourable and unfavourable interactions, respectively. For each AR subtype, a shell of residues contained within a $10 \AA$ distance from the ligand was considered for this analysis.

\section{Acknowledgements}

This work was supported by the Fondo di Ricerca di Ateneo (University of Camerino) and by a grant from the Italian Ministry for University and Research (PRIN2010-11 no. 20103W4779_003).

Keywords: adenine $\cdot$ adenosine $\cdot$ antagonists $\cdot$ molecular recognition $\cdot$ receptors

[1] B. B. Fredholm, A. P. IJzerman, K. A. Jacobson, J. Linden, C. E. Muller, Pharmacol. Rev. 2011, 63, 1-34.

[2] a) K. A. Jacobson, Z. G. Gao, Nat. Rev. Drug Discovery 2006, 5, 247-264; b) Handbook of Experimental Pharmacology, Vol. 193: Adenosine Receptors in Health and Disease (Eds.: C. N. Wilson, S. J. Mustafa), Springer, Berlin, 2009, pp. 1-652.

[3] C. E. Müller, K. A. Jacobson, Biochim. Biophys. Acta 2011, 1808, $1290-$ 1308.

[4] a) R. Dungo, E. D. Deeks, Drugs 2013, 73, 875-882; b) S. Uchida, K. Soshiroda, E. Okita, M. Kawai-Uchida, A. Mori, P. Jenner, T. Kanda, Eur. J. Pharmacol. 2015, 747, 160-165.

[5] a) E. Camaioni, S. Costanzi, S. Vittori, R. Volpini, K.-N. Klotz, G. Cristalli, Bioorg. Med. Chem. 1998, 6, 523-533; b) K.-N. Klotz, S. Kachler, C. Lambertucci, S. Vittori, R. Volpini, G. Cristalli, Naunyn-Schmiedeberg's Arch. Pharmacol. 2003, 367, 629-634; c) C. Lambertucci, G. Cristalli, D. Dal Ben, D. D. Kachare, C. Bolcato, K.-N. Klotz, G. Spalluto, R. Volpini, Purinergic Signalling 2007, 3, 339-346; d) C. Lambertucci, S. Vittori, R. C. Mishra, D. Dal Ben, K.-N. Klotz, R. Volpini, G. Cristalli, Nucleosides Nucleotides Nucleic Acids 2007, 26, 1443-1446; e) R. Volpini, D. Dal Ben, C. Lambertucci, G. Marucci, R. C. Mishra, A. T. Ramadori, K.-N. Klotz, M. L. Trincavelli, C. Martini, G. Cristalli, ChemMedChem 2009, 4, 1010-1019; f) C. Lambertucci, M. Buccioni, B. Cacciari, D. Dal Ben, S. Federico, K.-N. Klotz, G. Marucci, R. Volpini, G. Spalluto, G. Cristalli, Collect. Czech. Chem. Commun. 2011, 76, 1379-1393; g) C. Lambertucci, I. Antonini, M. Buccioni, D. Dal Ben, D. D. Kachare, R. Volpini, K.-N. Klotz, G. Cristalli, Bioorg. Med. Chem. 2009, 17, 2812-2822.

[6] R. Volpini, S. Costanzi, C. Lambertucci, F. R. Portino, S. Taffi, S. Vittori, J. A. Zablocki, K.-N. Klotz, G. Cristalli, ARKIVOC 2004, $301-311$.

[7] C. Lambertucci, M. Buccioni, D. Dal Ben, S. Kachler, G. Marucci, A. Spinaci, A. Thomas, K.-N. Klotz, R. Volpini, MedChemComm 2015, 6, 963-970.

[8] T. Borrmann, A. Abdelrahman, R. Volpini, C. Lambertucci, E. Alksnis, S. Gorzalka, M. Knospe, A. C. Schiedel, G. Cristalli, C. E. Muller, J. Med. Chem. 2009, 52, 5974-5989.

[9] a) K.-N. Klotz, J. Hessling, J. Hegler, C. Owman, B. Kull, B. B. Fredholm M. J. Lohse, Naunyn-Schmiedeberg's Arch. Pharmacol. 1997, 357, 1-9; b) K.-N. Klotz, N. Falgner, S. Kachler, C. Lambertucci, S. Vittori, R. Volpini, G. Cristalli, Eur. J. Pharmacol. 2007, 556, 14-18.

[10] M. Buccioni, G. Marucci, D. Dal Ben, D. Giacobbe, C. Lambertucci, L. Soverchia, A. Thomas, R. Volpini, G. Cristalli, Purinergic Signalling 2011, 7, $463-468$.

[11] G. Schulte, B. B. Fredholm, Mol. Pharmacol. 2000, 58, 477-482.

[12] A. Pinna, E. Tronci, N. Schintu, N. Simola, R. Volpini, S. Pontis, G. Cristalli, M. Morelli, Neuropharmacology 2010, 58, 613-623.

[13] a) V. P. Jaakola, M. T. Griffith, M. A. Hanson, V. Cherezov, E. Y. Chien, J. R. Lane, A. P. IJzerman, R. C. Stevens, Science 2008, 322, 1211-1217; b) D. Dal Ben, C. Lambertucci, G. Marucci, R. Volpini, G. Cristalli, Curr. Top. Med. Chem. 2010, 10, 993-1018; c) W. Liu, E. Chun, A. A. Thompson, P. Chubukov, F. Xu, V. Katritch, G. W. Han, C. B. Roth, L. H. Heitman, A. P. IJzerman, V. Cherezov, R. C. Stevens, Science 2012, 337, 232-236.

[14] Molecular Operating Environment, Chemical Computing Group Inc., 1255 University St., Suite 1600, Montreal, QC, H3B 3X3 (Canada).

[15] J. J. Stewart, J. Comput.-Aided Mol. Des. 1990, 4, 1-105.

[16] a) R. Huey, G. M. Morris, A. J. Olson, D. S. Goodsell, J. Comput. Chem. 2007, 28, 1145-1152; b) G. M. Morris, R. Huey, W. Lindstrom, M. F. Sanner, R. K. Belew, D. S. Goodsell, A. J. Olson, J. Comput. Chem. 2009, 30, 2785-2791; c) S. Dallakyan, A. J. Olson, Methods Mol. Biol. 2015, $1263,243-250$ 
[17] D. Dal Ben, M. Buccioni, C. Lambertucci, A. Thomas, K.-N. Klotz, S. Federico, B. Cacciari, G. Spalluto, R. Volpini, Eur. J. Med. Chem. 2013, 70, $525-$ 535.

[18] J. A. Ballesteros, H. Weinstein, Methods Neurosci. 1995, 25, 366-428.

[19] G. Lebon, K. Bennett, A. Jazayeri, C. G. Tate, J. Mol. Biol. 2011, 409, 298 310.

[20] H. Shadnia, J. S. Wright, J. M. Anderson, J. Comput.-Aided Mol. Des. 2009 23, $185-194$.

[21] a) D. Dal Ben, M. Buccioni, C. Lambertucci, G. Marucci, A. Thomas, R. Volpini, G. Cristalli, Bioorg. Med. Chem. 2010, 18, 7923-7930; b) D. Dal Ben, M. Buccioni, C. Lambertucci, A. Thomas, R. Volpini, in silico Pharmacol. 2013, 1, 24; c) F. Varano, D. Catarzi, L. Squarcialupi, M. Betti, F. Vincenzi,
A. Ravani, K. Varani, D. Dal Ben, A. Thomas, R. Volpini, V. Colotta, Eur. J. Med. Chem. 2015, 96, 105-121.

[22] A. De Lean, A. A. Hancock, R. J. Lefkowitz, Mol. Pharmacol. 1982, 21, 516.

[23] Y. Cheng, W. H. Prusoff, Biochem. Pharmacol. 1973, 22, 3099-3108.

[24] W. D. Cornell, P. Cieplak, C. I. Bayly, I. R. Gould, K. M. Merz, D. M. Ferguson, D. C. Spellmeyer, T. Fox, J. W. Caldwell, P. A. Kollman, J. Am. Chem. Soc. 1995, 117, 5179-5197.

Received: December 23, 2015

Revised: February 26, 2016

Published online on $\mathbf{\square}$ u, 0000 


\section{FULL PAPERS}

A. Thomas, M. Buccioni, D. Dal Ben,

C. Lambertucci, G. Marucci, C. Santinelli,

A. Spinaci, S. Kachler, K.-N. Klotz,

R. Volpini*

口-

The Length and Flexibility of the 2Substituent of 9-Ethyladenine Derivatives Modulate Affinity and Selectivity for the Human $A_{2 A}$ Adenosine Receptor

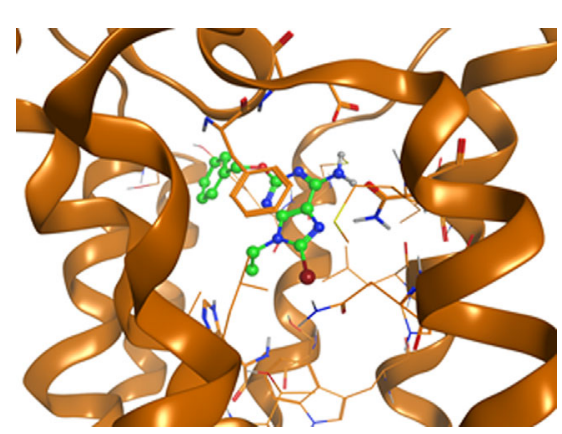

Size matters: Substituted 9-ethyladenine derivatives were synthesised and tested for affinity to the human $A_{2 A}$ adenosine receptor. The new adenine derivatives behave as $A_{2 A}$ adenosine receptor antagonists with half-maximal inhibitory concentration values in the nanomolar range. Molecular modelling studies provide a description of the possible binding mode of the compounds and an interpretation of the affinity data. 